\title{
EFEKTIFITAS PEMBINAAN RELIGIUSITAS LANSIA TERHADAP PERILAKU KEAGAMAAN (STUDI PADA LANSIA AISYIYAH DAERAH BANYUMAS)
}

\author{
Zakiyah $^{1}$, Darodjat ${ }^{2}$ \\ ${ }^{1}$ Universitas Muhammadiyah Purwokerto, Email : zakiyah.ump@gmail.com \\ ${ }^{2}$ Universitas Muhammadiyah Purwokerto, Email : darodjat.jt@gmail.com
}

\begin{abstract}
ABSTRAK
Usia lansia merupakan usia-usia yang perlu mendapatkan perhatian dari semua fihak. Dalam rangka menyiapkan dan meningkatkan kesejahteraan lansia, beberapa upaya perlu dilakukan secara terpadu dan lintas sektor, termasuk di dalamnya pembinaan religiusitas lansia sehingga lansia sehat jasmani, rohani dan religious. Penelitian bertujuan mengidentifikasi dan menganalisis efektifitas pembinaan religiusitas lansia Aisyiyah Daerah Banyumas terhadap perilaku keagamaannya. Penelitian merupakan penelitian deskriptif kualitatif dengan subjek penelitian para lansia yang mengikuti pembinaan religiusitas, para narasumber dan pimpinan Daerah Aisyiyah Banyumas (Majlis Tabligh). Data dikumpulkan melalui observasi, wawancara mendalam dan dokumentasi, sedangkan analisis data dengan reduksi data, penyajian data dan penarikan kesimpulan.

Hasil penelitian menunjukkan bahwa pembinaan religiusitas lansia Aisyiyah Daerah Banyumas efektif dalam membentuk perilaku keagamaan lansia, hal tersebut dibuktikan dari tujuan dan komitmen penyelenggara dalam pembinaan religiusitas lansia serta dukungan para narasumber yang mumpunnyai dengan indikator yakni penyampain materi sesuai dengan karakteristik dan kebutuhan lansia, penguasaan materi, metodologi yang tepat, media yang menarik, situasi dan kondisi yang kondusif. Keefektifan pembinaan religiusitas lansia dalam membentuk perilaku lansia juga dapat dibuktikan dari para lansia yang menyatakan bahwa perilakunya bertambah baik setelah mengikuti pembinaan religiusitas lansia dengan indikator yakni ideologi bertambah kuat dalam bertauhid (mengesakan Allah), ritual/ ibadah juga bertambah istiqomah, pengalaman keagamaan juga bertambah, intelektual (keilmuan tentang keagamaan juga bertambah termasuk semangat untuk terus mendapatkan ilmu keagamaan), dan konsistensi dalam menjalankan keagamaan juga semakin kuat.
\end{abstract}

Kata Kunci: Efektifitas; Pembinaan; Religiusitas

\begin{abstract}
The elderly are the ages that need attention from all parties. In order to prepare and improve the welfare of the elderly, several efforts need to be carried out in an integrated and cross-sectoral manner, including the development of elderly religiosity so that the elderly are physically, spiritually and religiously healthy. The aim of this research is to identify and analyze the effectiveness of the guidance of the elderly Aisyiyah Banyumas Region religiosity towards their religious behavior. The research is a qualitative descriptive study with research subjects of the elderly who participate in the fostering of religiosity, resource persons and leaders of the Aisyiyah Banyumas Region (Majlis Tabligh). Data collected through observation, in-depth interviews and documentation, while data analysis by data reduction, data presentation and drawing conclusions.
\end{abstract}

The results showed that the fostering of religious religiosity of the Aisyiyah Banyumas Region was effective in shaping the elderly religious behavior, this was evidenced from the goals and commitment of the organizers in fostering elderly religiosity as well as the support of resource persons who were qualified with indicators namely material delivery in accordance with the characteristics and needs of the elderly, mastery of material, appropriate methodology, interesting media, conducive situations and conditions. The effectiveness of fostering old-age religiosity in shaping the behavior of the elderly can also be proven from the elderly who state that their behavior improves after participating in fostering old-age religiosity with indicators that ideology becomes stronger in monotheism (insisting on God), rituals / worship also increases istiqomah, religious experience also improves, intellectual 
(religious knowledge also increases including the spirit to continue to gain religious knowledge), and the consistency in practicing religion is also getting stronger.

Keywords: Effectiveness; Coaching; Religiosity

\section{PENDAHULUAN}

Kehidupan manusia dimulai ketika manusia lahir dengan dibekali fitrah oleh Allah SWT kemudian menjadi seorang bayi kemudian tumbuh menjadi anak-anak dengan segala potensi dan kemampuan yang dimilikinya kemudian menjadi dewasa dan selanjutnya menjadi lansia atau lanjut usia. Perjalanan hidup manusia yang demikian merupakan fitrah dan qudrah Allah yang tidak seorangpun dapat menghindari dan menolaknya. Lanjut usia atau menjadi tua merupakan proses alami yang dialami oleh semua makhluk. Pada manusia proses tersebut ditandai oleh menurunya beberapa aspek, terutama aspek physiologis, psikis, dan fungsi-fungsi sensio motorik, sedangkan aspek lainya yang dipengaruhi oleh pengalaman malah justru meningkat. Dalam hal ini dikenal dua teori yang menerangkan manusia dengan kegiatanya yaitu teori disangegement dan teori aktivity (Suardiman, 1995). Teori yang pertama mengatakan bahwa semakin tinggi usia manusia akan diikuti secara berangsur-angsur oleh semakin mundurnya interaksi sosial, fisik dan emosi dengan kehidupan di dunia, sedangkan dengan teori yang kedua mengatakan bahwa semakin tua seseorang maka akan semakin memelihara hubungan fisik, sosial dan emosialnya.

Pada masa lansia, (Jalaluddin,1999) seseorang cenderung mengalami kemunduran fungsi, baik secara fisik, psikologis maupun sosial. Penurunan secara fisik pada umumnya dipengaruhi menurunnya fungsi pembuluh darah, khususnya pembuluh darah kapiler. Akibatnya jumlah darah yang mengalir ke organ tubuh menjadi menurun, sehingga mengakibatkan pengerutan organ tubuh. Dampak pada otak manusia adalah kemunduran fungsi daya ingat. Masyarakat awam sering menyebutnya pelupa atau pikun. Secara psikis, terjadi pula perubahan khas berupa gejala kecemasan, cenderung menjadi kurang bersih, dan gejala paranoid lainnya seperti keras kepala, egoistis, mudah tersinggung, mudah marah, mudah curiga, gelisah, dan sebagainya.

Manifestasi individual masa lansia, sebagian besar dipengaruhi oleh kepribadian masing-masing individu dalam mengendalikan diri. Religiusitas atau kepemilikan dalam hal ini memiliki peranan kuat dalam pengendalian diri lansia. Lansia yang mengamalkan agama dengan baik dan istiqomah akan mampu mengendalikan dirinya dengan baik begitu sebaliknya sehingga agama mempunyai peran penting dalam control perilaku lansia dalam menghadapi kehidupannya., dengan kata lain seseorang yang memiliki religiusitas yang tinggi dan kuat maka semakin mampu mengendalikan diri dalam menjalani kehidupannya.

Lansia merupakan usia lanjut yang sudah banyak waktu untuk meningkatkan religiusitasnya. Orang berusia lanjut lebih tertarik pada aktivitas yang berhubungan 
dengan sosial keagamaan dan hal-hal yang mampu menjadikan dirinya sebagai orang yang bermanfaat baik dirinya sendiri maupun orang lain. Hal tersebut dikarenakan pada masa usia lanjut seseorang sudah tidak lagi dibebani dengan tanggungan keluarga dan pekerjaan sehingga mereka lebih tertarik untuk menyibukkan diri dalam pengamalan keagamaan. Hasil penelitian Daaleman, Perera dan Studenski, 2004; Fry, 1999; Koenig \& Larson, (1998) menyatakan bahwa orang berusia lanjut lebih tertarik pada aktivitas yang berhubungan dengan sosial keagamaan. Agama dapat memenuhi beberapa kebutuhan psikologis yang penting pada lansia dalam hal menghadapi kematian, menemukan dan mempertahankan perasaan berharga dan pentingnya dalam kehidupan, dan dapat menerima kekurangan di masa tua. Kegiatan di bidang sosial dan keagamaan merupakan salah satu aktivitas yang dapat diikuti para lansia. Kegiatan ini cenderung tidak mengikat, dilakukan dengan sukarela, tidak ada paksaan, diliputi rasa kasih sayang terhadap sesama dan yang terpenting semakin mendekatkan diri para lansia dengan Tuhan (Santrock, 2006).

Hasil studi dari Seybold \& Hill, (2001) menyatakan bahwa ada hubungan yang positif antara religiusitas atau spiritualitas dengan well being, kepuasan pernikahan, dan keberfungsian psikologis, serta hubungan yang negatif dengan bunuh diri, penyimpangan, kriminalitas, dan penggunaan alkohol dan obat-obatan terlarang (Papalia, 2008). hal ini mungkin terjadi karena dengan beribadah dapat mengurangi stress dan menahan produksi hormone stress oleh tubuh, seperti adrenalin. Pengurangan hormone stress ini dihubungkan dengan beberapa keuntungan pada aspek kesehatan, termasuk system kekebalan tubuh yang semakin kuat. Dapat dikatakan semakin kuat lansia mendekatkan dirinya kepada Tuhan maka akan semakin sehat secara fisik dan psikhisnya.

Sementara itu religiusitas merupakan sikap kepemilikan seseorang terhadap agamanya yang menjadi karakter pribadinya yang selanjutnya akan teraplikasikan dalam perilaku keseharian yang berupa perilaku nyata. Religiusitas menjadi sangat penting bagi seseorang karena dengan religiusitas maka perilaku seseorang akan selalu terkontrol dan menjadi orang yang selalu ada dalam perilaku kebaikan sebagai refleksi orang yang memiliki keagamaan. Aisyiyah Daerah Banyumas merupakan suatu organisasi perempuan Muhammadiyah yang ada di Kabupaten Banyumas yang bergerak di bidang sosial kemasyarakatan, amar makruf nahi mungkar yang memberikan kemaslahatan bagi umat, masyarakat ,bangsa dan dunia kemanusiaan secara keseluruhan. Organisasi ini mempunyai tujuan mengantarkan warga masyarakat menjadi masyarakat yang utama yang mampu menjadi hamba (abdun) dan khalifah Allah (khalifatullah) di muka bumi yang sukses.

Organisasi ini mempunyai beberapa kegiatan yang dihimpun dalam suatu majlis-majlis atau seksi-seksi yang mempunyai tugas dan tanggung jawab yang berbeda-beda, seperti majlis ekonomi dan ketenagakerjaan yang mengurusi 
ekonomi dengan berbagai kegiatannya, majlis kader yang bertanggung jawab terhadap pembinaan kader yang nantinya diharapkan mampu menjadi penerus generasi senior, majlis tabligh yang mengurusi peningkatan kualitas keberagamaan warga Aisyiyah yang selama ini kegiatannya mampu memberikan pencerahan dan peningkatan kualitas keagamaan para lansia.

\section{METODE PENELITIAN}

Penelitian merupakan penelitian lapangan (field research), sedangkan pendekatan penelitian menggunakan pendekatan deskriptif kualitatif, yaitu suatu pendekatan penelitian yang bermaksud untuk memahami fenomena dan gejala segala sesuatu yang dialami oleh subjek penelitian berupa perilaku, tindakan, persepsi, motivasi, secara menyeluruh/ holistik dengan cara deskripsi atau pemaparan dalam bentuk kata-kata dan bahasa pada konteks alamiah dengan menggunakan berbagai metode ilmiah. Dalam hal ini adalah konteks efektifitas pembinaan religiusitas lansia pada Aisyiyah Daerah Banyumas terhadap perilaku keagamaannya. Subjek penelitian adalah para lansia yang mengikuti pembinaan religiusitas di Aisyiyah Daerah Banyumas, yang aktif mengikuti pembinaan religiusitas, disamping juga para narasumber yang membina kegiatan pembinaan religiusitas lansia dan juga Majlis Tabligh Pimpinan Daerah Aisyiyah (PDA) Banyumas selaku penyelenggara pembinaan religiusitas lansia di Pimpinan Daerah Aisyiyah Banyumas.

Teknik pengumpulan data dalam penelitian ini adalah observasi atau pengamatan yakni melihat dari dekat pelaksanaan pembinaan riligiusitas lansia Asiyiyah Daerah Banyumas dari perencanaan pembinaan, implementasi dan hasil dari pembinaan religiusitas serta efektifitas pembinaan religiusitas terhadap perilaku keagamannya. Kedua, wawancara yakni untuk menggali data tentang efektifitas pembinaan riligiusitas lansia Asyiyiyah Daerah Banyumas terhadap perilaku keagamaannya. Ketiga, dokumentasi yakni tulisan dan catatan peristiwa yang terkait dengan pembinaan riligiusitas lansia Asiyiyah Daerah Banyumas terhadap perilaku keagamaan seperti dokumen program kerja majlis Tabligh Pimpinan Daerah Aisyiyah Banyumas, presensi hadir dan materi-materi pembinaan religiusitas lansia.

Analisis data merupakan proses berkelanjutan yang membutuhkan refleksi terus menerus terhadap data yang diperoleh terkait dengan, mengumpulkan data, mengkatagorisasikan data dan menulis catatan singkat hasil penelitian yang selanjutnya dilaporkan sebagai hasil penelitian. Menurut Miles dan Huberman (2014), bahwa analisis data penelitian kualitatif dapat dilakukan melalui tiga alur kegiatan yang terjadi secara bersamaan dilakukan oleh peneliti yaitu : 1) reduksi data (data reduction), 2) penyajian data (data displays), 3) penarikan kesimpulan (conclusion drawing). Analisis data dalam penelitian ini mengkatogorisasikan, mereduksi, menyajikan data dan menyimpulkan data tentang efektifitas pembinaan 
riligiusitas lansia Asyiyiyah Daerah Banyumas terhadap perilaku keagamaannya.

\section{HASIL DAN PEMBAHASAN}

Pembinaan adalah usaha tindakan dan kegiatan yang dilakukan secara berdaya guna untuk memperoleh hasil yang baik. Menurut Arifin (2008), pembinaan yaitu usaha manusia secara sadar untuk membimbing dan mengarahkan kepribadian serta kemampuan seseorang, baik dalam pendidikan formal maupun non formal. Pembinaan pada anak-anak maksudnya memberikan arah penting dalam masa perkembangan anak, khususnya dalam perkembangan sikap dan perilaku. Untuk itu, pembinaan bagi anak-anak pasti sangat diperlukan sejak dini guna memberikan arah dan penentuan pandangan hidupnya.

Religiusitas berasal dari kata religi, religion (Inggris), religie (Belanda), religio (Latin), dan dien (arab). Menurut Drikarya(1999), kata religi berasal dari bahasa Latin religio yang akar katanya religare yang berarti mengikat. Maksudnya adalah suatu kewajiban - kewajiban atau aturan-aturan yang harus dilaksanakan, yang kesemuanya itu berfungsi untuk mengikat dan mengukuhkan diri seseorang atau sekelompok orang dalam hubunngannya dengan Tuhan atau sesama manusia, serta alam semesta. Beberapa ahli menganggap bahwa diri manusia terdapat suatu insting atau naluri yang disebut sebagai naluri beragama (religious instink), yaitu suatu naluri untuk meyakini dan mengadakan penyembahan terhadap suatu kekuatan diluar diri manusia. Naluri inilah yang mendorong manusia untuk mengadakan kegiatan-kegiatan religius. Key Pers menggunakan istilah motif teologis untuk menjelaskan dorongan pada manusia untuk mengadakan hubungan dengan Tuhan.

Religiusitas seseorang tidak hanya ditampakkan dengan sikap yang tampak, namun juga sikap yang tidak tampak yang terjadi dalam hati seseorang. Oleh sebab itu terdapat beberapa faktor yang mempengaruhi religiusitas seseorang. Faktor-faktor yang sudah diakui bisa menghasilkan sikap keagamaan, faktor-faktor itu terdiri dari empat kelompok utama, pengaruh-pengaruh sosial, berbagai pengalaman, kebutuhan dan proses pemikiran . Thouless. (1971) menyebutkan beberapa faktor yang mungkin ada dalam perkembangan sikap keagamaan yaitu; 1) pengaruh pendidikan atau pengajaran dan berbagai tekanan sosial (faktor sosial). 2) berbagai pengalaman yang membantu sikap keagamaan, (faktor alami). Pada pengalaman ini yang dimaksud faktor alami adalah seseorang mampu menyadari bahwa segala sesuatu yang ada di dunia ini adalah karena Allah SWT, misalnya seseorang sedang mengagumi keindahan laut, langit, keindahan hutan dan sebagainya.

Lansia merupakan usia-usia yang tidak banyak terbebani dengan kehidupan duniawi. Para lansia biasanya banyak mempunyai waktu luang untuk membekali dirinya dengan kegiatan-kegiatan keagamaan yang merupakan kebutuhan 
kerohanian yang urgen dalam kehidupannya sehingga hidupnya lebih nyaman dan bahagia secara kejiwaan. Glock dan Stark (Ancok, 1994) mengemukakan aspek religiusitas dalam lima dimensi, yaitu :

1. Religious of beliefs (ideological), pada aspek ini seseorang menerima hal-hal yang dogmatis dalam agamanya, misalnya percaya tentang adanya wujud Tuhan, adanya malaikat, adanya nabi atau rasul di masa lalu, percaya akan adanya hari kiamat, percaya adanya surga dan neraka.

2. Religious of practice (ritualistic), yaitu tingkatan sejauh mana seseorang berkaitan dengan kegiatan-kegiatan ritual atau ibadah baik yang umum seperti sholat, puasa, haji maupun ibadah yang umum seperti berbuat baik dengan orang lain, ramah, dan lain-lain

3. Religious of feeling (experiential), adalah bentuk-bentuk perasaan dan pengalaman yang dialami dan dirasakan oleh seseorang berkaitan dengan agamanya, misalnya merasa tenang seusai menjalankan sholat, merasakan kecemasan seusai mengerjakan sesuatu yang dilarang oleh agama

4. Religious of knowledge (intellectual), yaitu sejauh mana individu mempunyai minat mempelajari, mengamalkan dan percaya terhadap ilmu-ilmu agama.

5. Religious of effect (consequential), yaitu sejauhmana perilaku seseorang konsekuen dengan ajaran agama, misalnya menolong orang lain atau rela memberikan hartanya bagi kepentingan agamanya.

Beberapa hasil penelitian menunjukkan bahwa dari kebutuhan lansia maka kebutuhan akan agama merupakan kebutuhan pokok dan urgen para lansia. Koenig HG (2007) menyatakan agama membantu hadapi kematian, menjaga keberartian makna hidup, religiusitas berkorelasi positif dengan wellbeing, kepuasan pernikahan, keberfungsian psikologis, berkorelasi negatif dengan bunuh diri, krimanal dan penyimpangan psikologis.

Hasil penelitian Parker, Roff, Klemmack, Koenig, Baker and Allman (2003) mereka yang tinggi pada tiga dimensi religiusitas dilaporkan lebih sedikit memiliki gejala depresi dan lebih baik kesehatan mental dibanding mereka yang lebih rendah pada tiga dimensi religiusitas. Menurut Koenig \& Larson, 1998 agama dapat menambah kebutuhan psikologis yang penting pada older-adults, membantu mereka menghadapi kematian, menemukan dan menjaga sense akan keberartian dan signifikansi dalam hidup, serta menerima kehilangan yang tak terelakkan dari masa tua (Santrock, 2006).

Lanjut usia merupakan istilah tahap akhir dari proses penuaan. BKKBN (1998), dalam mendefinisikan batasan penduduk lanjut usia melihat ada tiga aspek yang perlu dipertimbangkan yaitu aspek biologi, aspek ekonomi dan aspek sosial. Secara biologis penduduk lanjut usia adalah penduduk yang mengalami proses penuaan secara terus menerus, yang ditandai dengan menurunnya daya tahan fisik yaitu semakin rentannya terhadap serangan penyakit yang dapat menyebabkan 
kematian. Hal ini disebabkan terjadinya perubahan dalam struktur dan fungsi sel ,jaringan, serta sistem organ. Secara ekonomi, penduduk lanjut usia lebih dipandang sebagai beban dari pada sebagai sumber daya. Banyak orang beranggapan bahwa kehidupan masa tua tidak lagi memberikan banyak manfaat, bahkan ada yang sampai beranggapan bahwa kehidupan masa tua, seringkali dipersepsikan secara negatif sebagai beban keluarga dan masyarakat. Sementara itu Islam menyatakan bahwa usia lanjut merupakan sunnatullah (ketetapan Allah ) yang tidak dapat diubah dan tidak seorangpun dapat mengelak dan menolaknya . Pada usia ini adalah usia - usia yang perlu dihormati dan dihargai oleh anak dan orang muda lainnya. Bahkan perlu dirawat dan dibantu segala kebutuhannya sesuai dengan (QS Luqman : 14) “Dan Kami perintahkan kepada manusia (berbuat baik) kepada kedua orang ibu bapaknya, ibunya telah mengandungnya dalam keadaan lemah yang bertambah tambah dan menyapihnya dalam dua tahun. Bersyukurlah kepada Ku dan kepada kedua orang ibu bapakmu, hanya kepada Ku lah kembalimu".

Agama bagi seseorang merupakan hal mutlak yang dibutuhkan dalam hidupnya, karena agama merupakan fitrah manusia.Agama tak dapat dipisahkan dari kehidupan manusia.Pengingkaran manusia terhadap agama dikarenakan faktor-faktor tertentu baik yang disebabkan oleh kepribadian seseorang maupun lingkungan dimana sesorang itu berada. Menurut Jalaluddin (1995 : 137) "Untuk menutupi atau meniadakan sama sekali dorongan dan rasa keagamaan tampaknya sulit dilakukan. Manusia ternyata memiliki unsur batin yang cenderung mendorongnya untuk tunduk kepada Dzat yang Ghaib. Ketundukan ini merupakan bagian dari faktor intern manusia yang dalam psikologi dinamakan pribadi (self) atau hati nurani (conscience of man).

Dalam konsep agama Islam, agama merupakan fitrah manusia sebagaimana diinformasikan dalam Al-Qur'an (QS Ar-Rum : 30) "Maka hadapkanlah wajahmu dengan lurus kepada agama (Allah), tetaplah atas fitrah Allah yang telah menciptakan manusia menurut fitrah itu, tidak ada perubahan pada fitrah Allah. Itulah agama yang lurus tetapi kebanyakan manusia tidak mengetahuinya" Fitrah Allah maksudnya ciptaan Allah sejak awal penciptaan. Manusia diciptakan Allah mempunyai naluri beragama yaitu agama Tauhid. Kalau ada manusia tidak beragama Tauhid maka hal itu hanya karena pengaruh lingkungan dan hasil pendidikan yang ia peroleh dalam kehidupannya.

Dalam agama terdapat beberapa ajaran dan perilaku yang harus dijalankan dan diamalkan oleh pemeluknya. Seseorang yang beragama dapat dikatakan sebagai penganut agama yang taat manakala sesorang mau dan dengan suka rela menjalankan dan mengamalkan ajaran agamanya dalam kehidupannya atau mau mengamalkan perilaku keagamaan dalam kehidupan kesehariannya. Perilaku keagamaan adalah beberapa perbuatan yang dilakukan oleh seseorang dalam rangka 
pengamalan keagamaan yang dianutnya. Perilaku keagamaan ini merupakan hal penting dalam kehidupan seseorang dalam menjalankan agama yang dipeluknya dan dia termasuk orang yang beragama atau memiliki keagamaan Perilaku keagamaan merupakan refleksi dari orang yang beragama, dan setiap agama pasti mengajarkan perilaku-perilaku tertentu yang harus dilakukan oleh penganut agama tersebut sehingga orang yang beragama akan merasa tentram dalam menjalani hidupnya. Agaknya cukup logis kalau setiap ajaran agama mewajibkan penganutnya untuk melaksanakan ajaran agamanya secara rutin. Bentuk dan pelaksanaan ibadah agama paling tidak akan ikut berpengaruh dalam menanamkan keluhuran budi yang pada puncaknya akan menimbulkan rasa sukses sebagai pengabdi Tuhan yang setia. Tindak ibadah setidak-tidaknya akan memberi rasa bahwa hidup menjadi lebih bermakna, dan manusia sebagai makhluk yang memliki kesatuan jasmani dan rohani secara tak terpisahkan memerlukan perlakuan yang dapat memuaskan keduanya.

Kehidupan keagamaan seseorang akan mencerminkan religiusitasnya. Religiusitas adalah suatu kesatuan unsur-unsur yang komprehensif, yang menjadikan seseorang disebut sebagai orang beragama (being religious), dan bukan sekedar mengaku mempunyai agama (having religion). Religiusitas meliputi pengetahuan agama, pengalaman agama, keyakinan agama, pengamalan ritual agama, pengalaman agama, perilaku (moralitas) agama, dan sikap sosial keagamaan. Selanjutnya tingkat religiusitas diketahui melalui kualitas kehidupan seseorang dalam interaksinya dengan Tuhan, sesama manusia, dan alam semesta yang disertai keterikatan dan ketaatan manusia terhadap agama yang dianutnya, mempunyai kesiapan dan tanggungjawab untuk melaksanakan ajaran agama.

Pembentukan kehidupan beragama (tingkat religiusitas) individu dipengaruhi oleh beberapa faktor lingkungan dan faktor perkembangan kehidupan beragama yang mengalami perkembangan dari fase kehidupan yang satu ke fase kehidupan yang lain. Para psikologi agama mengacu pada teori perkembangan, teori yang sering dipakai sebagai dasar adalah teori perkembangan kognitif dari Piaget dan Erikson. Kehidupan agama seseorang tidak mengalami banyak perubahan setelah dewasa. Diketahui bahwa pada orang-orang dewasa awal keyakinan secara umum dan afiliasi agama tetap sama atau lebih sering menetap daripada yang berubah (Parker, 1996). Thoulless (2000) membedakan faktor-faktor yang mempengaruhi sikap keagamaan menjadi empat macam, yaitu :

1. Pengaruh pendidikan dan pengajaran serta berbagai pengaruh sosial dalam sikap keagamaan. Pendidikan dari orangtua, tradisi sosial, tekanan lingkungan sosial mempunyai pengaruh bagi individu untuk menyesuaikan diri dengan berbagai pendapat dan sikap yang disepakati oleh lingkungan.

2. Berbagai pengalaman yang membuat sikap keagamaan terutama pengalaman mengenai keindahan keselarasan dan kebaikan dari dunia lain (faktor alami), 
konflik moral (faktor moral), dan pengalaman emosional keagamaan (faktor afeksi).

3. Faktor yang seluruhnya atau sebagian timbul dari kebutuhan-kebutuhan yang tidak terpenuhi terutama kebutuhan akan rasa aman, cinta kasih, harga diri dan ancaman kematian.

4. Berbagai proses pemikiran (faktor intelektual), sebagai contoh masuknya atau beralihnya seseorang dari satu agama ke agama yang lain karena dia menemukan temuan ilmiah yang ada hubungannya dengan sesuatu yang ada dalam kitab suci.

Efektifitas pembinaan religiusitas lansia Aisyiyah Daerah Banyumas berdasarkan temuan di lapangan efektif dalam membentuk perilaku keagamaan lansia, hal tersebut dibuktikan dari hasil wawancara dengan informan tentang berbagai hal yang menyangkut keektifan pembinaan religiusitas lansia di Aisyiyah yakni diawali dari filosofi diselenggarakannya pembinaan religiusitas lansia di Aisyiyah yakni; terutama karena perintah Allah SWT, amar makruf nahi mungkar dan ini juga menjadi dasar/ filosofi didirikannya organisasi Muhammadiyah termasuk Aisyiyah sehingga Aisyiyah berkomitmen untuk membina religiustas lansia dengan menyiapkan narasumber yang mumpuni.

Beberapa hal yang menunjukkan keefektifan pembinaan religiusitas lansia di Aisyiyah terhadap perilaku lansia adalah :

1. Tujuan mengikuti pembinaan religiusitas lansia

2. Latar belakang para lansia mengikuti pembinaan

3. Dampak pembinaan religiusitas terhadap perilaku lansia di Aisyiyah

4. Pembinaan religiusitas efektif dalam membentuk perilaku lansia (idiologi, ritual, pengalaman, intelektual dan konsistensi)

5. Pembinaan religiusitas yang dipraktekkan sesuai dengan kebutuhan lansia

Masa lanjut usia adalah salah satu tahap perkembangan manusia, yang berlangsung setelah usia 60 tahun. Pada masa lanjut usia, seseorang biasanya sudah pensiun dari pekerjaannya. Masa pensiun, bagi sebagian lansia dimaknai sebagai saat dimilikinya kebebasan untuk menentukan kegiatan yang akan dilakukannya. Mereka dapat memuaskan keinginannya menyalurkan hobby, mengembangkan bakat dan minatnya, bersilaturahmi, rekreasi, berorganisasi, berolahraga atau kegiatan yang dulu sulit dilakukan. Mereka tidak lagi dikejar deadline, membuat laporan, mentaati jam kerja atau memenuhi target. Di sisi lain, ada lansia yang merasa kebingungan mengisi waktu, tidak ada teman bicara, merasa tidak terpakai lagi, tidak ada yang menghormati, tidak menghasilkan karya apapun dan hanya duduk-duduk sepanjang hari bahkan merasa menjadi beban keluarga. Menjadi sangat penting mempersiapkan usia lanjut menjadi usia yang bahagia, yang penuh manfaat kehidupannya dan selalu optimis dalam menjalani kehidupan. 
Diantara pentingnya mempersiapkan masa lansia menjadi lansia yang bahagia, sehat dan produktif adalah dengan pembinaan religiusitasnya. Berdasarkan beberapa hasil penelitian menujukkan bahwa masa usia lansia adalah masa-masa seseorang butuh religiusitas untuk menjadikan lansia mampu mengamalkan keagamaannya dengan baik sehingga hidupnya akan semakin tenang, tentram dan dekat dengan Tuhannya.

Pembinaan religiusitas lansia yang diselenggarakan oleh Majlis Tabligh PDA (Pimpinan Daerah Aisyiyah) Banyumas berdasarkan hasil temuan di lapangan menunjukkan efektif dalam membentuk perilaku lansia, hal tersebut dapat dibuktikan dari beberapa hal yakni; 1) tujuan ingin mengetahui berbagai hal yang terkait dengan pengamalan keagamannya, meningkatkan ketaqwaan dan memperbaiki akhlaq/ perilakunya, 2) latar belakang mengikuti pembinaan adalah agar para lansia semakin bertambah ilmu agamanya sehingga aqidahnya semakin kuat, ibadahnya semakin istiqomah dan perilaku atau akhlaqnya semakin baik 3) dampak mengikuti pembinaan religiusitas adalah banyak ilmu, amar makruf nahi mungkar, hidup lebih sabar dan pengamalan keagamaan insyaallah juga lebih baik termasuk perilaku keagamaan, 4) pembinaan religiusitas efektif dalam membentuk perilaku lansia (idiologi, ritual, pengalaman, intelektual dan konsistensi), 5) bukti keefektifan pembinaan religiusitas adalah; a) Idiologi semakin kuat, ibadah semakin istiqomah dan perilaku pengamalan keagamaan juga insyaallah semakin baik dan konsisten, b) Lansia semakin semangat ingin mengikuti pembinaan di Aisyiyah, c) Berusaha menyalurkan sedikit rizqi untuk bersodaqoh, d) Semakin sehat lahir dan batin, 6) pembinaan religiusitas yang dipraktekkan di Aisyiyah selama ini juga sudah sesuai dengan kebutuhan lansia yakni para lansia yang butuh tambahan ilmu agama untuk peningkatan amalan keagamaannya dan perbaikan perilakunya.

Beberapa temuan di lapangan tersebut menunjukkan bahwa pembinaan religiusitas yang diselenggarakan oleh Majlis Tabligh PDA (Pimpinan Daerah Aisyiyah) Banyumas mampu membekali lansia dengan ilmu yang bermafaat untuk meningkatkan keberagamaan lansia sehingga lansia semakin kuat aqidahnya, istiqomah ibadahnya sekaligus mampu merubah perilakunya menjadi lebih baik sehingga lansia menjadi lebih tenang dan tentram hidupnya. Berdasarkan temuan diatas dapat disimpulkan bahwa pembinaan religiusitas lansia yang diselenggarakan Pimpinan Daerah Aisyiyah (PDA) Banyumas efektif dalam membentuk perilaku lansia lebih baik. Diawali dari tujuan para peserta mengikuti pembinaan untuk menambah ilmu keagamaan, menjalin silaturrahim diantara para peserta, komitmen penyelenggara dengan memfasilitasi sarana prasarana yang dibutuhkan, semangat para peserta pembinaan dan juga narasumber yang mumpuni di bidangnya, penyampaian materi yang menarik, tidak monoton sehingga peserta pembinaan semangat untuk mengikuti pembinaan.

Beberapa perilaku hasil pembinaan religiusitas tersebut dibuktikan dari 5 
indikator yakni idiologi atau keyakinan semakin kuat terhadap eksistensi Allah, ritual atau peribadatan semakin rajin dan istiqomah dalam beribadah, pengalaman keagamaan juga bertambah karena bertambahnya ilmu yang diperoleh, intelektual atau wawasan keilmuan semakin banyak bertambah ilmu termsuk semangat untuk menuntut ilmu dan yang terakhir lansia semakin konsistensi dalam menjalankan agama.

\section{SIMPULAN}

Berdasarkan temuan dilapangan dapat disimpulkan bahwa pembinaan religiusitas lansia di Pimpinan Daerah Aisyiyah (PDA) Banyumas efektif dalam membentuk perilaku keagamaan lansia, hal tersebut dibuktikan dengan beberapa hal yakni; pertama, Tujuan para lansia mengikuti pembinaan adalah ingin mengetahui berbagai hal yang terkait dengan pengamalan keagaaman, meningkatkan ketaqwaan dan memperbaiki akhlaqnya atau perilakunya Kedua, komitmen penyelenggara (Majlis Tabligh Aisyiyah Daerah Banyumas) dalam penyelenggaraan pembinaan religiusitas lansia dengan menyiapkan narasumber yang mumpuni, tempat pembinaan yang nyaman, pemilihan hari dan jam yang tepat untuk pembinaan (setiap hari ahad, pukul 07.30 -08.30).

Ketiga, dukungan para narasumber yang mumpuni dengan indikator; 1) penyampaian materi sesuai dengan karakteristik dan kebutuhan lansia, 2) penguasaan materi para narasumber, 3) metodologi yang tepat dan variatif, 4) media yang menarik, 5) situasi dan kondisi yang kondusif., 6) penyampaian materi yang tidak monoton serta ada sesi tanya jawab dan praktek bagi peserta pembinaan keempat, keefektifan pembinaan dalam membentuk perilaku lansia dapat dibuktikan dari para lansia yang menyatakan bahwa perilakunya bertambah baik setelah mengikuti pembinaan religiusitas lansia dengan indikator; 1) idiologi bertambah kuat dalam bertauhid (mengesakan Allah), 2) ritual/ ibadah juga bertambah istiqomah, 3) pengalaman keagamaan juga bertambah, 4) intelektual ( keilmuan tentang keagamaan juga bertambah termasuk semangat untuk terus mendapatkan ilmu keagamaan) dan 5) konsistensi dalam menjalankan keagamaan juga semakin kuat. Disamping itu keefektifan pembinaan religiusitas lansia terhadap perilaku keagamaan, setelah mengikuti pembinaan lansia semakin tahu banyak tentang ilmu agama sehingga bisa beribadah sesuai dengan contoh yang diajarkan nabi Muhammad SAW dan ibadah tidak hanya sekedar ikut-ikutan orang lain tapi tahu dasarnya (Al-Qur'an dan Al-Hadist).

\section{DAFTAR PUSTAKA}

Arifin, (2010), Hubungan Timbal Balik Pendidikan Agama (Jakarta: Bulan Bintang Al-Qurthubi, Ibnu 'Abd Allah Muhammad Ibn Ahmad Anshari, tt, Tafsir al-Qurthuby Kairo, Dar al-Sa’ab : Juz VI, 5106. 
Al-Ghazali, Abu Hamid Muhammad, (1989), Ihya'Ulum al-din, Beirut : Dar al-Fikr, Jilid III

Bungin, Burhan. (2006). Metodologi Penelitian Kualitatif. Jakarta : PT. Raja Grafindo Persada.

Biswan, (2013), Aktifitas Spiritual dan Semangat Hidup Penyandang Disabilitas Paraplegia, Jurnal Health Quality Vol. 3 No. 2

Departemen Pendidikan Nasional (2008), Kamus Besar Bahasa Indonesia, Jakarta : Pusat Bahasa.

Crain, William, (2007), Teori Perkembangan , Konsep dan Aplikasi, terjamah, Yudi Santoso, Edisi Ketiga, Yogyakarta : Pustaka Pelajar.

Creswell, John. W, (2009), Research Design Pendekatan Kualitatif, Kuantitatif dan Mixed, Tarj, Achmad Fawaid (2014), Yogyakarta : Pustaka Pelajar.

Fauzan Adhim, (2012), Pengaruh Religiusitas Terhadap Prestasi Kerja, Jakarta, Erlangga.

Hurlock, E.B.(1980). Psikologi Perkembangan. Terjemahan. Jakarta : Erlangga

Jalaluddin. (2005). Psikologi Agama. Jakarta : PT. Raja Grafindo Persada.

Jurnal Modernisasi (2009), Volume 5, Nomor 2, Juni 2009

Koenig HG. (2007). Religion and remission of depression in medical inpatients with heart failure/pulmonary disease. Journal of Nervous and Mental Disease

Miles, M.B., dan Hubermen, A.M, (2003), Analisis data Kualitatif, (Tarjamah). Tjetjep Rohidi dan Mulyarto, Jakarta : Universitas Indonesia Press.

Nurcholis, Majid (2012), Psikologi Agama, Jakarta, PT Raja Grafindo

Papalia. (2006). Psikologi Perkembangan. Terjemahan. Jakarta : Kencana Prenada Media Group.

Parker, M., dkk. (2003). Religiosity and Mental Health In Southern, Community Dwelling Older Older Adults. Aging \& Mental Health.

Santrock. (2006). Life-Span Development. Terjemahan. Jakarta : Erlangga.

Sarwono, (2006), Metode Penelitian Kualitatif, Jakarta, PT Raja Grafinda Persada.

Thouless. (2000). Pengantar Psikologi Agama. Terjemahan. Jakarta : PT. Raja Grafindo Persada.

Zakiyah, Labib, Makhful, (2013), Model Pembinaan Nilai-Nilai Agama pada Lansia, Hasil IbM, Tidak diterbitkan, Fakultas Agama Islam Universitas Muhammadiyah Purwokerto 